\title{
MILK PRODUCTIVITY OF SIMMENTAL COWS AUSTRIAN SELECTION
}

\author{
Anatoly Shevhuzhev ${ }^{1}$, Nikolai Belik ${ }^{1}$, Eugene Emelyanov ${ }^{2}$, Alexander Tokar ${ }^{2}$ \\ ${ }^{1}$ Saint-Petersburg State Agrarian University, Russian Federation; \\ ${ }^{2}$ Yaroslav-the-Wise Novgorod State University, Russian Federation \\ segwan@ rambler.ru
}

\begin{abstract}
The article presents data characterizing milk production and milk quality indicators of Simmental cows' Austrian selection of different productive types in the process of adaptation for the conditions of foothills of the North Caucasus, the Russian Federation. Simmental cows' milk type by the amount of milk produced is surpassing the cows (meat-dairy and dairy-meat) at the first lactation on 815 and $1934 \mathrm{~kg}$ at the second lactation - 904 and $2114 \mathrm{~kg}$ and at the third -834 and $2030 \mathrm{~kg}$. Analysis of the data revealed relatively high and stable lactation throughout the control period of the cows of all productive types. The content of dry matter, fat and protein in milk was more from the cows of meat-dairy type productivity. The content of nonessential amino acids in milk from the cows of meat-dairy type was more than from dairy cows by $14.5 \%$, dairy-meat by $9.6 \%$; the sum of essential amino acids -11.6 and 7.2 \%. During lactation, the number of essential amino acids and the total amino acid content decreased in milk from cows all of productive types. The Austrian Simmental cattle breeding different production types characterized as adaptable to the conditions of the North Caucasus foothills.
\end{abstract}

Keywords: Simmental cows' Austrian selection, dairy cattle, milk production.

\section{Introduction}

The Simmental is among the oldest and most widely distributed of all breeds of cattle in the world. Early records indicate that Simmental cattle were the result of a cross between large German cattle and a smaller breed indigenous to Switzerland. Although the first official herdbook was established in the Swiss Canton of Berne in 1806, there is evidence of large, productive "red and white" cattle being found much earlier in ecclesiastical and secular property records of Western Switzerland [1]. Those red and white animals were highly sought because of their "rapid growth development; outstanding production of milk, butter and cheese; and for their use as draught (draft) animals." They were known for their gentle nature, impressive stature and excellent dairy qualities [2].

Since its origin in Switzerland, the breed has spread to all six continents. Total numbers are estimated between 40 and 60 million Simmental cattle worldwide, with more than half in Europe. The worldwide spread was gradual until the late 1960's. Records show that a few animals were exported to Italy as early as the 1400's. During the 19th century, Simmentals were distributed through most of Eastern Europe, the Balkans and Russia [3-5].

Simmental breed heifers and semeen re-started to be imported after the year 2000, mainly from Austria and Germany. One of the reasons of the Simmental importations is that small and medium scale farm owners of costal and hilly areas are satisfied with milk \& meat production of this breed (dualpurpose cattle) [6].

The cows of the Simmental breed are able to well adapt into foothill conditions and combine high genetic potential of milk and meat productivity [7]. However, between these productive characteristics different physiological nature exists, and by the breeding process there is a tendency to deviation of animal productivity into greater milk yield or meat productivity. Forming different productive types it is important to understand how the adaptation process will interact with the new climatic and economic conditions of the region [8]. The aim of the research is to study milk production and milk quality indicators of Simmental cows' Austrian selection of different productive types in the process of adaptation to the conditions of foothills of the North Caucasus, the Russian Federation.

\section{Materials and methods}

For the experiment 149 cows were selected, their milk productivity and qualitative indicators of milk were studied. The studied population was contained in one place and serviced by the same operators during three lactations. The productivity by the first lactation was assessed of 149 cows, by the second lactation - 132 cows, and the third by 112 cows (Table. 1 ). 
After the first calving from productive use $11.5 \%$ of cows were eliminated, after the second another $15.2 \%$, and to the third calving there were only $75.1 \%$ of the cows left from the original herd [9].

Table 1

Results of milk productivity of cows of different productive types

\begin{tabular}{|c|c|c|c|c|c|c|}
\hline \multirow{2}{*}{ Type of cows } & \multirow{2}{*}{$n$} & \multirow{2}{*}{$\begin{array}{c}\text { Milk yield per } \\
\text { lactation, } k g\end{array}$} & \multicolumn{2}{|c|}{ Content in milk, \% } & \multicolumn{2}{|c|}{ Content in milk, kg } \\
\hline & & & fat & protein & fat & protein \\
\hline \multicolumn{7}{|c|}{1 lactation } \\
\hline Dairy cattle & 51 & $5766 \pm 154.2$ & $4.09 \pm 0.03$ & $3.26 \pm 0.01$ & $235.9 \pm 3.0$ & $188.1 \pm 2.2$ \\
\hline $\begin{array}{l}\text { Dairy-meat } \\
\text { cattle }\end{array}$ & 73 & $4951 \pm 106.2$ & $4.11 \pm 0.02$ & $3.29 \pm 0.01$ & $203.5 \pm 2.3$ & $162.9 \pm 1.6$ \\
\hline $\begin{array}{l}\text { Meat-dairy } \\
\text { cattle }\end{array}$ & 25 & $3832 \pm 125.8$ & $4.16 \pm 0.04$ & $3.34 \pm 0.02$ & $159.3 \pm 2.4$ & $128.0 \pm 1.7$ \\
\hline $\begin{array}{l}\text { Average by } \\
\text { herd }\end{array}$ & & 5040.1 & 4.11 & 3.29 & 207.1 & 165.7 \\
\hline \multicolumn{7}{|c|}{2 lactation } \\
\hline Dairy cattle & 49 & $6092 \pm 153.2$ & $4.04 \pm 0.04$ & $3.24 \pm 0.01$ & $246.1 \pm 3.9$ & $197.3 \pm 2.9$ \\
\hline $\begin{array}{l}\text { Dairy-meat } \\
\text { cattle }\end{array}$ & 61 & $5188 \pm 114.4$ & $4.10 \pm 0.03$ & $3.27 \pm 0.01$ & $212.7 \pm 2.9$ & $172.2 \pm 2.4$ \\
\hline $\begin{array}{l}\text { Meat-dairy } \\
\text { cattle }\end{array}$ & 21 & $3978 \pm 125.2$ & $4.14 \pm 0.04$ & $3.32 \pm 0.02$ & $164.7 \pm 2.5$ & $132.1 \pm 2.5$ \\
\hline $\begin{array}{l}\text { Average by } \\
\text { herd }\end{array}$ & & 5106.0 & 4.08 & 3.26 & 207.5 & 165.8 \\
\hline \multicolumn{7}{|c|}{3 lactation } \\
\hline Dairy cattle & 46 & $6087 \pm 152.2$ & $4.03 \pm 0.05$ & $3.21 \pm 0.01$ & $245.3 \pm 4.4$ & $195.4 \pm 3.2$ \\
\hline $\begin{array}{l}\text { Dairy-meat } \\
\text { cattle }\end{array}$ & 49 & $5253 \pm 113.9$ & $4.08 \pm 0.03$ & $3.26 \pm 0.01$ & $218.7 \pm 3.0$ & $174.7 \pm 2.6$ \\
\hline $\begin{array}{l}\text { Meat-dairy } \\
\text { cattle }\end{array}$ & 17 & $4057 \pm 134.5$ & $4.11 \pm 0.05$ & $3.30 \pm 0.03$ & $166.7 \pm 2.2$ & $133.9 \pm 2.7$ \\
\hline $\begin{array}{l}\text { Average by } \\
\text { herd }\end{array}$ & - & 5168.6 & 4.06 & 3.24 & 210.5 & 176.4 \\
\hline
\end{tabular}

Mostly animals of meat-dairy type were eliminated: $16.0 \%$ after the first calving and $32.0 \%$ of the initial amount to the third calving. Almost similarly were the cows of dairy-meat type eliminated: $16.5 \%$ after the first calving and $32.9 \%$ after the second calving. Among dairy cows after the first calving $4.0 \%$ of animals were eliminated, after the second calving 9.9 percent from the initial amount. It shows that dairy cows are characterized by longer production that is highly important for assessing the reproductive ability of the breed or type and the ability to adapt to new conditions.

The data were analyzed using PROC MIXED (SAS Version 9.2, Cary, NC, USA) as a split plot with the main unit in a completely randomized design with a $3 \times 2 \times 2$ factorial arrangement of treatments [10]. The experiment unit was the cow. The initial linear models included the effects of the particle size (fixed), the method of evaluation (fixed), particle sizexmethod interaction (fixed), cow nested in the particle size and the method of evaluation (random, main unit error), time of adaptation (fixed), timexparticle size (fixed), timexmethod (fixed), timexparticle sizexmethod (fixed) and a random residual error. Linear models were reduced according to standard model reduction conventions. Generally, the time of adaptation effects and associated interactions were not important and were removed from the final models. Digestibility estimates were regressed on the particle size using initial linear models including both linear and quadratic components. Heterogeneity of regression was tested where interactions of the particle size and the method of evaluation occurred in the analyses fitting the particle size as a classification variable. The level of significance adopted was $p<0.05$, while $0.05 \leq p<0.10$ was considered as indicative of a trend. 


\section{Results and discussion}

Studying milk production, the cows of the Simmental breed revealed significant differences between productive inbreeding types by received from them milk, milk fat, and protein.

From Simmental cows of the dairy type, the milk yield was greater than dairy-meat and meatdairy cows by the first lactation on 815 and $1934 \mathrm{~kg}(16.5$ and $50.4 \%)$, by the second lactation -904 and $2114 \mathrm{~kg}$ (17.4 and $53.1 \%)$ and the third -834 and $2030 \mathrm{~kg}(15.8$ and $50.1 \%)$. The highest content of fat and protein were in milk from the meat-dairy type of cows - 4.16 and 3.34 percent, the lowest into milk from the dairy type of cows 4.09 and $3.26 \%$ and the dairy-meat type of cows -4.11 and $3.29 \%$.

By the first lactation from dairy cows $235.9 \mathrm{~kg}$ of milk fat were received, that is by 32.4 and $76.6 \mathrm{~kg}$ more than from dairy-meat and meat-dairy type of cows; by the second lactation -32.4 and $44.2 \mathrm{~kg}$, by the third -33.4 and $81.4 \mathrm{~kg}$. For three lactations milk protein from animals of the dairy type was obtained by $186.8 \mathrm{~kg}$ more than of the meat-dairy type of cows and more by 71.0 per $\mathrm{kg}$ than the dairy-meat type of cows; milk fat by 236.6 and $92.4 \mathrm{~kg}$.

By live weight throughout the research the advantage was on the side of the animals of the meatdairy type. They surpassed the cows of the milk type at the first lactation by $43 \mathrm{~kg}$, by the third $60 \mathrm{~kg}$. The advantages of the cows of the meat-dairy type over the dairy-meat type by live weight were $15 \mathrm{~kg}$ and $20 \mathrm{~kg}$. With increasing significantly the age, the differences by live weight between cows of productive types increase in favor of the meat-dairy type.

Cows of different types distinguished high stability coefficient of milk production. By the first three lactations it changed from dairy cows from 9.56 to 9.65 ; dairy-meat from 7.79 to 8.04 and meatdairy from 5.89 to 6.01 .

The lactation curve (Fig. 1) characterizing dynamics of the milk yield of cows during lactation shows that in cows of different type higher milk yield is observed at the third month of lactation, with a gradual decline in subsequent months of lactation.

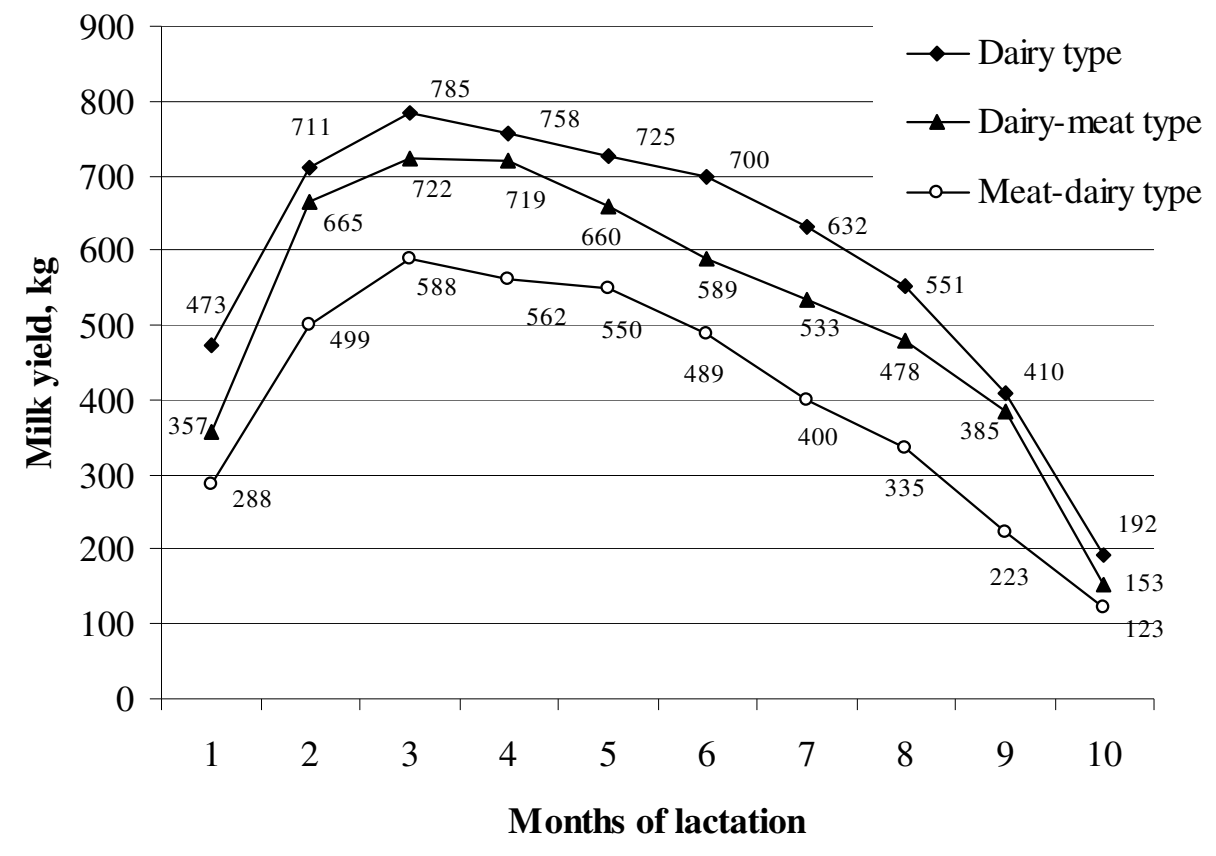

Fig. 1. Lactation curves of cows

Analysis of the lactation curves also shows a relatively high and stable lactation throughout the control period, what is confirmed by the coefficient of stability of lactation (CSL). In dairy cows, dairy-meat and meat-dairy types it is $90.2 ; 88.6 ; 85.9 \%$.

The qualitative composition of milk from cows of different types shown in Table 2, the data show, that more dry matter, fat and protein is found in milk from the cows of the meat-dairy type, less in milk from the cows of the dairy type. 
Animals of dairy-meat type are between dairy and meat-dairy types. And this ranking distribution by the qualitative composition of milk is observed for all of the three lactations. Milk from animals of different productivity types is characterized by a pretty high content fat and protein that determine the calorie content of the product and the highest content of casein in milk was from the cows of the meatdairy type, the lowest in milk from dairy cattle. The lowest concentration of lactose in milk was from dairy cattle $-4.49-4.45 \%$, from meat-dairy cows there was the highest content of this component 4.52 to $4.54 \%$. Cow's milk from all of the types has high energy value, and the difference between the groups was insignificant. It should be noted that by comparison with the first-month lactation to the fifth the content of protein in milk from dairy cows decreased from $33.1 \mathrm{~g} \cdot \mathrm{kg}^{-1}$ to $28.7 \mathrm{~g} \cdot \mathrm{kg}^{-1}$ $(15.3 \%)$, from the dairy-meat and meat-dairy cows by 13.5 and $11.3 \%$.

Table 2

Chemical composition the milk of Simmental cows

\begin{tabular}{|c|c|c|c|c|c|c|c|c|c|}
\hline \multirow[b]{2}{*}{$\begin{array}{l}\text { Type of } \\
\text { cows }\end{array}$} & \multirow[b]{2}{*}{$\begin{array}{c}\text { Dry } \\
\text { matter, \% }\end{array}$} & \multicolumn{7}{|c|}{ Content in milk, \% } & \multirow{2}{*}{$\begin{array}{c}\text { Energy } \\
\text { value } 1 \\
\text { kg milk, } \\
\text { MJ }\end{array}$} \\
\hline & & fat & protein & casein & $\begin{array}{c}\text { whey } \\
\text { proteins }\end{array}$ & lactose & ash & $\begin{array}{l}\text { nonfat } \\
\text { milk } \\
\text { solids }\end{array}$ & \\
\hline \multicolumn{10}{|c|}{1 lactation } \\
\hline Dairy & 12.53 & 4.09 & 3.26 & 2.85 & 0.41 & 4.49 & 0.69 & 8.63 & 2.92 \\
\hline $\begin{array}{c}\text { Dairy- } \\
\text { meat }\end{array}$ & 12.59 & 4.11 & 3.29 & 2.86 & 0.43 & 4.50 & 0.69 & 8.66 & 3.0 \\
\hline $\begin{array}{l}\text { Meat- } \\
\text { dairy }\end{array}$ & 12.72 & 4.16 & 3.34 & 2.88 & 0.46 & 4.53 & 0.69 & 8.72 & 3.07 \\
\hline \multicolumn{10}{|c|}{2 lactation } \\
\hline Dairy & 12.43 & 4.04 & 3.24 & 2.83 & 0.41 & 4.47 & 0.68 & 8.59 & 2.93 \\
\hline $\begin{array}{c}\text { Dairy- } \\
\text { meat }\end{array}$ & 12.56 & 4.10 & 3.27 & 2.86 & 0.41 & 4.50 & 0.69 & 8.66 & 3.00 \\
\hline $\begin{array}{l}\text { Meat- } \\
\text { dairy }\end{array}$ & 12.67 & 4.14 & 3.32 & 2.87 & 0.45 & 4.52 & 0.69 & 8.69 & 3.09 \\
\hline \multicolumn{10}{|c|}{3 lactation } \\
\hline Dairy & 12.37 & 4.03 & 3.21 & 2.82 & 0.39 & 4.45 & 0.68 & 8.57 & 2.91 \\
\hline $\begin{array}{c}\text { Dairy- } \\
\text { meat }\end{array}$ & 12.52 & 4.08 & 3.26 & 2.85 & 0.41 & 4.49 & 0.69 & 8.63 & 2.92 \\
\hline $\begin{array}{l}\text { Meat- } \\
\text { dairy }\end{array}$ & 12.64 & 4.11 & 3.30 & 2.88 & 0.42 & 4.54 & 0.69 & 8.73 & 3.08 \\
\hline
\end{tabular}

\section{Conclusions}

1. By milk production for three lactations, the Simmental cow's Austrian selection of the dairy type has the best result. From the cows of the milk type the highest yield of milk, milk fat and protein was obtained. In average for three lactations, milk yield per cow of this type was superior to the other by 851 and $2028 \mathrm{~kg}$. But the specific content of dry matter, fat, and protein in milk was more from the cows of the meat-dairy type.

2. The results identify the herd as productive with steady lactation curves. In the cows of the dairy type the coefficients of usefulness lactation $(74.4 \%$ ) were the greatest, for the cows of the other types they were 71.7 and $68.0 \%$, which is typical for cows with aligned lactation. These cows were used longer in the herd and they often recorded the highest lifetime milk yield.

3. The obtained results characterize the Simmental cattle of different productive types as adaptable to foothill conditions.

\section{References}

1. Åby, B.A., Aass, L., Sehested, E., Vangen, O. A bio-economic model for calculating economic values of traits for intensive and extensive beef cattle breeds. Livestock Science, 143 (2-3), pp. 259-269. 
2. Arango, J.A., Cundiff, L.V., Van Vleck, L.D. Breed comparisons of Angus, Charolais, Hereford, Jersey, Limousin, Simmental, and South Devon for weight, weight adjusted for body condition score, height, and body condition score of cows. Journal of Animal Science, 80 (12), pp. 31233132 .

3. Arthur, P.F., Makarechian, M., Berg, R.T., Weingardt, R. Longevity and lifetime productivity of cows in a purebred Hereford and two multibreed synthetic groups under range conditions. Journal of animal science, 71 (5), pp. 1142-1147.

4. Дедов, М.Д., Сивкин Н.В. Увеличение производства молока и повышение его качества в летний период (Increasing milk production and improving its quality in the summertime). Зоотехния, 2004, No 8, pp 21-24. (In Russian).

5. Смакуев Д.Р. Молочная продуктивность и качество молока симментальского скота австрийской селекции при использовании биологически активных веществ (Milk yield and milk quality of Austrian Simmental cattle breeding with using biologically active substances): автореф. дис. канд. сельск. наук, 2009, 147 р. (In Russian).

6. Chapman, H.D., Young, J.M., Morrison, E.G., Edwards, N.C. Differences in lifetime productivity of Herefords calving first at 2 and 3 years of age. J. Anim. Sci., 46, pp. 1159-1162.

7. Hickson, R.E., Lopez-Villalobos, N., Kenyon, P.R., Ridler, B.J., Morris, S.T. Profitability of calving heifers at 2 compared with 3 years of age and the effect of incidence of assistance at parturition on profitability. Animal Production Science, 50 (6), pp. 354-358.

8. Johnson, S.K., Deutscher, G.H., Parkhurst, A. Relationships of pelvic structure, body measurements, pelvic area and calving difficulty. Journal of animal science, 66 (5), pp. 10811088.

9. Núñez-Dominguez, R., Cundiff, L.V., Dickerson, G.E., Gregory, K.E., Koch, R.M. Lifetime production of beef heifers calving first at two vs three years of age. Journal of animal science, 69 (9), pp. 3467-3479.

10. Sadovoy, V., Omarov, R., Shlykov, S., Shchedrina, T. Assessment compliance of qualitative food characteristics to standard requirements. 15th International Scientific Conference on Engineering for Rural Development, May 25-27, 2016, Jelgava, Latvia, pp. 360-363. 